\title{
TANGGUNG JAWAB MENJALANKAN PROTOKOL KESEHATAN DI TENGAH PANDEMI COVID-19 DITINJAU DARI PERSPEKTIF ETIKA KRISTEN
}

\author{
Tony Salurante, Riste Tioma Silaen, Yane Keluanan, Yosia Belo \\ Sekolah Tinggi Teologi Injili Arastamar Jakarta \\ tony.salurante@sttsetia.ac.id
}

\begin{abstract}
This article describes the various views of Christian ethicists about the concept of responsibility. The paper attempts to better understand the meaning of responsibility for Christians during pandemic covid 19, particularly in carrying out health protocols. It is said that responsibility has relevance for human ethics-moral life and actions that reveal through His love. When the notion of responsibility is only associated with a mere duty ethic, it will be trapped in consequentialism. Responsibility in Christian ethics is the manifestation of good deeds based on the grace of faith. This is the essence of the Christian life. Responsibility in Christianity reflects loving God and neighbor, not just the right or wrong attitude because this action does not affect the promise of salvation. In the theological perspective, responsibility is seen as retrospective responsibility for past actions and the consequences before God.
\end{abstract}

Keywords: Christian ethics; responsibility; good works, covid-19, health protocol

\begin{abstract}
Abstrak. Artikel ini mendeskripsikan berbagai pandangan dari para etikus kristen tentang konsep tanggung jawab dari perspektif etika Kristen. Artikel ini berusaha memahami implikasi tanggung jawab bagi orang percaya di tengah pandemic Covid-19, khususnya dalam menjalankan protokol kesehatan. Dikatakan bahwa tanggung jawab memiliki relevansi bagi kehidupan etis-moral sebagai kesaksian menyatakan kasih Allah. Ketika seseorang melihat gagasan tanggung jawab hanya sebatas etika tugas semata maka akan terjebak dalam konsekuensialisme. Tanggung jawab dalam perspektif Etika Kristen adalah wujud dari perbuatan baik yang didasari iman yang diterima sebagai anugerah.tanggung jawab dalam kekristenan adalah cerminan mengasihi Allah dan sesama, bukan sekedar sikap yang benar atau tidak, karena perbuatan ini tidak mempengaruhi janji keselamatan. Dalam perspektif teologis, tanggung jawab terutama dilihat sebagai tanggung jawab retrospektif atas perbuatan di masa lalu dan konsekuensinya di hadapan Allah.
\end{abstract}

Kata kunci: etika Kristen; tanggung jawab; perbuatan baik, covid-19, protokol kesehatan

Komunitas religius memiliki kapasitas untuk berkontribusi pada kebaikan bersama di setiap konteksnya. Gereja adalah komunitas yang terpanggil untuk melakukan tujuan tersebut (bdk. Kis.13:47). Wujud dari pemahaman gereja tentang Allah (teologi) dinyatakan dalam sikap etismoralis setiap hari (praxis). Orang percaya yang meresponi perintah Allah 
dirangkum sebagai bentuk tanggung jawab orang percaya. Wells mengatakan: "Sekarang masalah etika teologis adalah tanggung jawab yang diembankan Tuhan kepada kita di mana Dia telah memerintahkan kita untuk bertanggung jawab" (Wells et al., 2017, hal. 100). Sejauh pemahaman manusia bahwa ia adalah ciptaan yang memiliki relasi dengan Allah maka setiap manusia akan bertangungjawab kepada Dia yang telah memberi perintah.

Menganalisa makna tanggung jawab dari perspektif etika Kristen merupakan tantangan sekaligus sebuah usaha relevan di zaman modern (Wannenwetsch, 2005) sekalipun sebagian besar teolog lebih tertarik memikirkan etika kebajikan (Lovin, 2009) yang nampak lebih sukses (D. De Villiers, 2006). Di samping itu yang lain menganggap wacana tanggung jawab sebagai penolakan sebagian teolog terhadap pilihan historis orang kristen yang sejalan dengan pemikiran, filosofi, dan komunitas non-kristen tentang masalah moral (Schweiker, 2009). Penelitian mengenai tanggung jawab bukanlah topik yang baru karena sudah cukup diteliti di Indonesia. Salah satunya adalah penelitian Susanta. Penulis ini menyatakan bahwa interaksi dengan sesama adalah hal yang penting dalam tanggung jawab. Tanggung jawab hanya mungkin terjadi apabila kita memperlakukan yang lain itu sebagai sahabat (Susanta et al., 2020).

Lalu bagaimana seseorang mampu bertangungjawab kepada sesama sekaligus kepada Allah? Apalagi di tengah pluralisme moral dan 
dominasi pikiran manusia modern yang semakin jauh dari kebenaran objektif Alkitab? Masalah ini perlu dijawab dari perspektif etika Kristen tentang bagaimana memaknai tanggung jawab terhadap sesama sebagai wujud tanggung jawab kepada Tuhan (Schweiker, 1999).

Saat ini dunia sedang mengalami pandemi Covid-19 yang telah menelan banyak korban jiwa, nyaris menghancurkan sendi-sendi kehidupan sosial ekonomi, serta berbagai kesulitan lain yang dihadapi masyarakat. Semua orang didorong untuk berpartisipasi mengatasi pandemi ini, termasuk umat Kristen. Bagaimana signifikansi pemahaman tentang gagasan tanggung jawab orang Kristen di tengah situasi ini?

Salah satu bentuk partisipasi masyarakat yang diminta pemerintah tertuang dari Keputusan Menteri Kesehatan Nomor Hk.01.07/Menkes/382/2020 untuk mengatasi pandemi ini adalah menjalankan protokol kesehatan yang diyakini akan mampu mengurangi penyebaran virus. Protokol itu terutama adalah menjaga jarak, memakai masker, dan mencuci tangan secara rutin di air mengalir ini mengikuti aturan dari KEPPRES No. 11/2020 tentang Penetapan Kedaruratan Kesehatan Masyarakat Corona Virus Disease 2019 (COVID-19) (Tuwu, 2020). Ini berarti setiap orang bertanggungjawab menjalankan protokol kesehatan sebagai bentuk partisipasi untuk mengurangi penyebaran virus dalam konteks negara hukum dan religius.

Namun faktanya masih saja banyak dijumpai masyarakat bersosialisasi tanpa memikirkan tanggung jawab tersebut. Tindakan yang 
mudah dilihat adalah ketika mereka belajar di pasar (Binti Mufarida, 2021), di objek wisata (Sukur, 2021), upacara kematian di Toraja (Kusuma, 2020). Karena mereka membahaya orang lain dan diri sendiri maka bisa dikatakan mereka kurang bertanggungjawab menjalani kehidupan sosial di tengah pandemi. Bahkan ada yang tetap mengerahkan massa seolah tidak peduli dengan penyebaran virus yang sedang meningkat di tengah pandemi sehingga terpaksa berurusan secara hukum seperti peristiwa kerumunan di petamburan Jakarta (Mansur, 2020).

Kekurangpedulian masyarakat untuk menjalankan protokol kesehatan turut berkontribusi pada lambatnya penanganan pandemi covid-19 di Indonesia. Dari 20 negara dengan kasus tertinggi Indonesia menempati posisi ke 14 dengan jumlah dari 1 juta jiwa pada tahun 2020 . (Amani, 2020). Kemudian, angka kematian cenderung naik di bulan mei 2021 sebesar 2,76\% seperti disampaikan oleh Doni Monardo sebagai ketua satgas Penanganan Covid-19 (Lotulung, 2021). Namun angka kesembuhan di bulan lalu terus naik sebesar $91 \%$. Terlihat bahwa usaha pemerintah untuk menyadarkan masyarakat pentingnya tanggung jawab dalam usaha menekan laju penyebaran pandemi Covid-19 hingga saat ini belum membuahkan hasil yang memuaskan.

Lebih lanjut, penelitian di kalangan teolog Kristen di Indonesia mengenai pandemi covid-19 sudah cukup banyak. Kaseke melihat ekses tidak langsung yang luput dari perhatian yaitu ekosistem alam yang membaik (Kaseke, 2020). Stevanus melihat pandemi dan ibadah di rumah 
sebagai sebuah kesempatan gereja mengkonsepkan ulang esensi sebagai wujud kasih, menghadirkan nilai-nilai "Kerajaan Allah" di muka bumi dan kepedulian (Luhukay, 2020).

Dari sekian banyak penelitian tersebut belum ada yang secara khusus memberi perhatian pada tanggung jawab menjalankan protokol kesehatan. Penelitian terhadap topik ini penting dilakukan untuk memberikan dasar teologis, khususnya bagi umat Kristen, untuk turut bertanggung jawab memutus mata rantai penyebaran covid-19 di Indonesia. Penelitian ini akan menjawab pertanyaan sentral bagaimana membangun konsep pemahaman tanggung jawab dalam perspektif etika Kristen sehingga setiap orang percaya dapat menjalani hidup praktis sesuai rencana Allah dalam situasi pandemi Covid-19?

\section{METODE}

Penelitian ini menggunakan metode kualitatif, dengan pendekatan deskriptif. Penulis menggunakan sumber utama dari beberapa teolog etika Kristen yang telah dahulu meneliti seputar topik ini. Baik yang dipublikasi dalam skala nasional maupun internasional. Hal ini untuk memperluas wawasan dari data-data yang relevan tanpa mengabaikan konteks nasional. Sudut pandang penelitian ini dilihat dari sudut etika Kristen karena etika Kristen memikirkan tentang ketaatan iman kepada Hukum Allah di tengah-tengah kenyataan hidup, yakni ketaatan yang dibangkitkan oleh Roh Kudus sendiri (Verkyul, 2018). 


\section{HASIL}

Berdasar kajian yang dilakukan didapatkan hasil bahwa konsep tanggung jawab mempunyai peran penting dalam situasi pandemi Covid19. Tanggung jawab ini merupakan aktualisasi respon terhadap anugerah Allah yaitu keselamatan yang diberikan Allah yang memampukan dan mendorong seseorang memuliakan dan mengasihi Allah. Tanggung jawab tersebut dinyatakan kepada sesama manusia maupun ciptaan lain. Lalu dari perspektif etika Kristen tanggung jawab beririsan dengan etika tugas, kewajiban, dan kebajikan. Sebuah kebajikan merupakan karakter etis yang perlu dilatih dan terus menerus dilakukan. Bisa dikatakan bahwa tanggung jawab pribadi terkait erat dengan hukum menabur dan menuai (lih. Gal. 6: 7-8 dan Yes. 3:10-11).

Tanggung jawab dalam konteks pandemi Covid 19 punya peran sentral didalamnya sebagai kontribusi orang percaya menghadapi virus tersebut. Berbagai aktifitas gereja pada masa pandemi yang menjadi terbatas menciptakan kesempatan bertindak untuk meresponi kebenaran Allah. Dengan gereja memahami gagasan tanggung jawab dapat berkontribusi dalam usaha mengurangi penyebaran virus Covid-19.

\section{PEMBAHASAN}

\section{Tanggung Jawab Merupakan Esensi dan Relasi}

Gagasan mengenai tanggung jawab terus disosialisaikan dalam masyarakat di banyak sektor kehidupan. Hidup sosial manusia pada esensinya bermuatan dengan tuntutan tanggung jawab. Tuntutan ini 
sebagian berada pada wilayah hukum negara. Dalam kehidupan gereja tuntutan tanggung juga cukup banyak ini berkaitan dengan hukum Allah.

Pemikiran ini sederhana namun kompleks, utamanya pada saat memperhatikan perkembangan studi etika di abad postmodern dalam etika terapan, teori kebajikan, etika naratif, dan jenis pemikiran etis nonformal lainnya. Dari semuanya ini gagasan tanggung jawab tetap sangat diperlukan sebagai orientasi perilaku manusia (Schweiker, 2009).

Tanggung jawab sering dikaitkan dengan perbuatan yang secara intrinsik atau konsekuensinya dievaluasi sebagai hal yang negatif. Namun Schweiker dengan jelas menunjukkan bagaimana tanggung jawab penting dikembangkan dalam hidup sehari-hari sebagai wujud pemahaman akan nilai-nilai tertentu. Secara sederhana pengertian tanggung jawab adalah tindakan untuk memiliki kendali dan otoritas atas sesuatu serta kewajiban untuk menjaganya. Dengan demikian seseorang yang mampu memenuhi tanggung jawabnya akan mendapatkan sesuatu yang bernilai.

Tanggung jawab dalam konteks ini merupakan titik awal untuk pengembangan studi etika yang koheren dan komprehensif. Dengan kata lain, tanggung jawab menjadi sebuah prinsip dan esensi manusia yang penting dalam kehidupan beretika. Gagasan tanggung jawab harus dipelihara, berproses, dan dilatih dalam perbuatan nyata bukan sekedar konsep atau ide belaka. Tanpa gagasan tanggung jawab, setiap individu ini akan kekurangan pemahaman diri yang aktual, karena masing-masing 
tidak akan memiliki sarana untuk menunjuk dirinya sendiri atau dirinya sebagai agen yang berinteraksi dengan orang lain.

Douma misalnya mengingatkan aspek asketika dalam kehidupan orang percaya. Ini sebagai latihan diri dalam kesalehan (1 Tim. 4:16). Tanggung jawab merupakan bentuk kesalehan atau sikap yang perlu melewati proses sehingga ia mampu berkontribusi kepada integritas manusia. Sederhananya, bagi Douma etika Kristen merupakan sebuah studi yang mengajarkan manusia tentang bagaimana hidup yang bertanggung jawab di hadapan Allah dan manusia (Douma, 2010). Latihan seperti ini tentu dipengaruhi oleh aspek eksternal dan internal, baik komunal maupun personal, yang saling mempengaruhi dan membentuk intergritas pribadi. Tanggung jawab itu sendiri bukanlah objek atau norma etika, melainkan wujud eksistensi moral, wujud yang diartikan sebagai penghormatan dan peningkatan keutuhan hidup (Schweiker, 2009).

Integritas hidup orang Kristen ditunjukkan dalam kehidupan seharihari karena ia dibangun oleh jalinan relasi yang saling berinterkasi yang satu dengan yang lain sebagai tanggung jawab. Barth berpandangan bahwa orang Kristen hidup dalam tanggung jawab. Segala keberadaan dan kemauan kita, apa yang kita lakukan dan apa yang tidak kita lakukan, adalah jawaban yang berkelanjutan atas Firman Tuhan yang disampaikan kepada kita sebagai perintah (dalam Wannenwetsch, 2005).

Tanggung jawab selalu dibarengi dengan kebebasan. Tanpa ada kebebasan manusia tidak perlu merasa bertanggung jawab akan hal 
apapun yang terjadi. Kebebasan merupakan ciri-ciri modernisme, tetapi gagasan modern tentang tanggung jawab bukanlah konsekuensialisme sederhana. Konsekuensialisme mengevaluasi tindakan dan pilihan berdasarkan hasilnya. Konsekuensialisme tidak bertanggung jawab atas pembalikan ironis yang menghasilkan, dalam jangka panjang, tindakan kita, justru kebalikan dari apa yang kita inginkan (Lovin, 2009).

Rasa tanggung jawab selalu ada di setiap manusia terlebih orang yang beragama. Orang Kristen memiliki tanggung jawab kepada Allah dan juga kepada manusia. Kondisi tersebut berkembang sampai kepada setiap area kehidupan lain. Narasi alkitabiah melihat pribadi manusia dipanggil oleh Tuhan dan dipanggil untuk mendapatkan jawaban. Pribadi manusia dipahami sebagai makhluk yang menjawab, responsif, dan karenanya bertanggung jawab. Dalam membentuk narasi ini secara lebih sistematis kita dapat membedakan antara empat dimensi keterkaitan manusia ini: dengan Tuhan, dengan dunia, dengan manusia lain, dengan diri sendiri (Huber, 2020).

Dalam diri orang percaya melekat apa yang disebut sebagai tanggung jawab retrospektif dan prospektif. Retrospektif berkaitan dengan perbuatan yang telah berlangsung dan segala konsekuensi yang terjadi menjadi bagian dalamnya, sedangkan prospektif berkaitan atas perbuatan yang akan datang (Bertens, 2013). Dalam perspektif teologis tanggung jawab terutama dilihat sebagai tanggung jawab retrospektif atas perbuatan di masa lalu dan konsekuensinya di hadapan Allah (Huber, 2020). Ada 
kewajiban dilakukan saat ini untuk mempengaruhi masa depan, hal itu semua merupakan tanggung jawab manusia seiring dengan rencana dan kehendak Allah (Kol. 3:2-4), baik sebagai individu maupun sebagai wakil Allah.

Douma mengatakan bahwa kita harus memikirkan situasi kondisi yang aktual dan konkret dengan kewajiban kita terhadap kehendak Allah (Douma, 2010). Tanggung jawab adalah konsep kompleks yang melibatkan gagasan tentang akuntabilitas dan kewajiban. Akuntabilitas melihat kembali ke beberapa perbuatan atau sikap yang sepatutnya dilakukan. Kewajiban menanti tuntutan moral untuk dipenuhi dalam hubungan. Tanggung jawab berkaitan dengan hubungan, perbuatan, dan sikap yang memberi pujian atau menunjukkan kesalahan (Cole, 1995). Dengan jelas Cole menegaskan bagaimana relasi dan perbuatan menjadi ukuran untuk menilai seberapa besar nilai seseorang. Dalam hal ini tanggung jawab memberikan akumulasi bagi seseorang untuk menerima penilaian sosial maupun lainnya.

Karl barth menegaskan bahwa tanggung jawab adalah tentang ketaatan pada perintah Tuhan, kebebasan untuk hidup yang berakar pada tindakan bebas Tuhan dalam Yesus Kristus. Tujuannya adalah mengartikulasikan hubungan konstitutif antara tindakan, identitas moral, kebaikan normatif, dan pandangan tentang ruang moral kehidupan (dalam Schweiker, 2009). Singkatnya, tanpa tanggung jawab sikap etis seseorang membias menjadi perbuatan tanpa makna. Tanggung jawab sebagai 
konsep etis sebagai artikulasi keyakinan atas perbuatan atau kegagalan mereka. Konsep ini tergantung dengan kebutuhan esensial pada pemahaman afirmatif tentang theonomi dan otonomi. Hanya dengan asumsi bahwa pribadi manusia adalah agen moral, dengan demikian kita dapat menerapkan gagasan tanggung jawab dalam kehidupan.

\section{Tanggung Jawab dari Perspektif Etika Kristen}

Kontribusi besar pemikiran tentang tanggung jawab dalam etika Kristen di abad modern telah dimulai oleh Dietrich Bonhoeffer dalam bukunya berjudul Discipleship dan H. R. Neibuhr dalam bukunya The Responsible Self. Etika dalam konsep Bonhoeffer (dalam Huber, 2020) tidak hanya tertarik pada pribadi manusia sebagai orang beriman yang taat, tetapi sebagai penjawab (answerer) dan penanggap (responder). Jadi, ketertarikannya beralih kepada interaksi antara panggilan (cal) dan jawaban (answer). Panggilan dilihat dari perspektif orang yang memanggil dan jawaban diminta untuk menanggapi panggilan ini. Panggilan dipahami sebagai aktivitas Tuhan di dalam Kristus. Responsnya adalah aktivitas manusia. Sehingga istilah yang tepat untuk tanggapan ini adalah "tanggung jawab". Bagi Neibuhr (dalam Lovin, 2009) diri yang bertanggung jawab adalah pembuat keputusan yang harus menahan godaan untuk memikirkan semua realitas dan kemungkinan tak terbatasnya, untuk fokus pada pilihan yang sebenarnya tersedia pada saat tertentu. Tanggung jawab adalah mengetahui bahwa kita adalah manusia, bukan Tuhan; seorang bertanggung jawab untuk membuat pilihan antara 
jahat dan baik, ia tidak bisa diam di tengah pilihan. Dilema ini mempertimbangkan berbagai kompleksitas yang rumit sebagai seorang manusia. Terutamanya situasi covid dengan banyak kebijakan pemerintah protokol kesehatan yang ketat yang mungkin saja berpengaruh langsung kepada sektor ekonomi dan spiritual dalam masyarakat.

Relasi tanggung jawab dalam perspektif etika terjalin sebagai kajian yang mengaitkan etika tugas (duty ethics), kebajikan (virtue ethics) dan kewajiban. Ketiganya tidak terpisahkan dalam konsep tanggungjawab. Sekalipun tanggung jawab penting, dari perspektif etika tanggung jawab tidak menentukan dan menjamin kebaikan moral suatu keputusan benar di suatu konteks. Kejatuhan Adam dan Hawa merupakan contoh bagaimana Allah hendak mempertanyakan tanggung jawab atas perbuatan mereka. Tanggung jawab cenderung dilihat dari sisi negatif dalam peristiwa ini. Namun dalam etika Kristen tanggung jawab dinilai dengan kesadaran akan syukur manusia kepada Allah - ini sudut pandang positif.

Dalam hal ini tindakan yang bertanggung jawab dalam arti yang memenuhi syarat secara teologis akan membutuhkan penilaian tentang tindakan kita sendiri pada konteks (Wannenwetsch, 2005). Awalnya tentu lingkungan sekitar menilai sebagai konsekuensi sosial. Pada tahap ini tindakan dan sikap memainkan peranan sebagai saksi bagi orang lain bagaimana Roh Allah bekerja memberikan dorongan untuk melakukan perbuatan bertanggungjawab. Dan yang terakhir, semua akan berkaitan kepada Allah sebagai pemberi hukum. Dalam hal ini penekanan alkitabiah 
tentang tanggung jawab ada di akhir setiap pribadi manusia atas perbuatannya tidak dapat disangkal. Tanggung jawab moral tidak dihilangkan dengan kepastian iman bahwa Tuhan mengatasi keberdosaan manusia dan memulihkan hubungan-Nya dengan manusia oleh kasih karunia-Nya (Huber, 2020). Dalam hal ini ia berjalan selaras sebagai bukti manusia mengasihi Allah yang dinyatakan dengan perbuatan, Yakobus mengingatkan untuk berbuat sesuatu sebagai iman kita (Yak. 2:14-26). Iman menjadi dasar penting perbuatan baik manusia, karena tanpa anugerah tersebut segala sesuatu yang diperbuat manusia di hadapan Allah ada salah (Rm.8:8; 14:23). Tanggung jawab Kristen lahir dari perbuatan baik yang didasari oleh iman, bukan kebajikan (virtue) manusia semata.

Roh Kudus adalah sumber kebaikan sehingga manusia mampu menanggung segala yang Allah perintahkan (Fil. 1:14). Hal ini merupakan integritas moral yang berkaitan pada kebaikan moral substantif dan karenanya fokus pada etika teologis. Dalam etika Kristen gagasan tentang tanggung jawab berfungsi menyediakan cara untuk memikirkan tentang arti kebaikan dan nilai-nilai bagaimana seseorang seharusnya hidup (E. De Villiers, 2013). Gagasan tanggung jawab dalam hal ini menjadi dasar bagi etika Kristen, karena mampu mendorong manusia untuk bertindak sesuatu dari hal yang ia yakini dan percaya. Villiers (2006) menilai Jonas dan Schwieker bisa saja salah karena telah mengangkat gagasan tanggung jawab menjadi pusat perhatian dalam etika kontemporer 
sebagai akibat dari resiko yang terlibat dengan perluasan radikal kekuatan manusia melalui perkembangan teknologi yang pesat.

Kewajiban ada tetapi bukan sekedar perintah imperatif belaka, tanggung jawab tidak bisa dihindari atau diabaikan, seketika seorang dewasa ia secara bertahap belajar tentang tanggung jawab. Di sini tanggung jawab bukanlah sebuah prinsip teleologis yang membuat orang percaya harus melakukan sesuatu untuk mendapatkan penghargaan di akhirnya. Tanggung jawab adalah tugas menjalankan kewajiban dengan sekedar dilimpahkan kepada orang-orang yang gagal membebaskan diri dari kesalahan, konsep tanggung jawab dalam etika Kristen membangunkan perasaan diri sebagai pribadi yang bertanggung jawab di mana identitasnya terikat kepada sesuatu yang ilahi dan duniawi (Severson, 2011). Hal tersebut menegaskan sketsa dari gambaran tentang relasi seseorang dalam kaitan hubungan manusia dengan Tuhan, manusia dengan manusia di hadapan Allah. Menurut Niebuhr (Niebuhr, 1963) ada beberapa elemen menyangkut diskusi tentang tanggung jawab: pertama, tanggung jawab adalah gagasan responsif; kedua bukan hanya tindakan responsif tetapi juga responsif sesuai dengan interpretasi kita tentang pertanyaan yang diberi jawaban; ketiga adalah reaksi antisipasi reaksi; keempat adalah solidaritas sosial. Lanjutnya Neiburh mengatakan bahwa tanggung jawab dapat didefinisikan sebagai gagasan dari tindakan seseorang yang merupakan respon atas suatu tindakan terhadap dirinya di mana respon tersebut sesuai dengan interpretasinya tentang tindakan 
yang diterimanya dan dengan ekspektasi mengenai tanggapan terhadap responnya tersebut; dan semua ini ada dalam suatu komunitas yang berkelanjutan" (Niebuhr, 1963).

Penjelasan tersebut menunjukkan bahwa manusia selalu memikirkan setiap perbuatan yang akan dilakukan terkait kepada masa depan. Kekristenan mengajarkan dosa turunan telah mengakibatkan manusia menjadi bersalah namun Kristus telah menanggung salah umat manusia di atas salib. Kemerdekaan inilah yang mendorong manusia untuk hidup mengikuti kehendak dan rencana Allah. Karena pada akhirnya segala sesuatu akan muncul dihadapan takhta penghakiman (Rm 1:18 32; Why. 14: 6-7; 20: 11-15).

Pandangan Nieburh pada satu sisi, memperhatikan afinitas asli dari simbol baru yaitu 'diri yang bertanggung jawab' dengan pola pemikiran modern yang biasanya berkisar pada nilai-nilai seperti interaksi, relasionalitas, dan akuntabilitas. Menjawab masalah yang disebabkan manusia dan berusaha menjawabnya untuk kepentingan umum belaka. Tetapi di sisi lain, Neiburh juga menemukan dalam konsep ini bisa menjadi kunci teoritis yang lebih cocok daripada simbol klasik untuk mengakses dan merepresentasikan etos alkitabiah sebagai norma historis kehidupan Kristen (Wannenwetsch, 2005). Keberadaan manusia yang bertanggung jawab kepada Allah dan sesamanya.

Rasul Paulus menyinggung makna tanggung jawab dalam bagian penutup dari suratnya kepada jemaat Korintus di pasal 15. Ini, menjadi 
tanggung jawab orang percaya: berdiri teguh dalam iman dan menyerahkan diri sepenuhnya dalam anugerah Tuhan. Penekanan alkitabiah tentang tanggung jawab lebih kepada masa penghakiman. Segala perintah Allah berlaku kepada semua umat manusia yang berpusat kepada Kristus yang berakhir pada kedatangan-Nya kedua. Namun demikian secara etis tanggung jawab tidak dihilangkan dengan kepastian iman bahwa Tuhan mengatasi keberdosaan manusia dan memulihkan hubungannya dengan manusia saat ini. Seseorang punya tanggung jawab tetapi tidak identik dengan perbuatannya. (Huber, 2020). Kedua konsep teologis tersebut penting bagi etika orang percaya dalam usaha membangun pemahaman tentang tanggung jawab di kehidupan. Bagi orang percaya tanggung jawab sepantasnya tidak dihayati hanya sekedar tindakan menjawab saja tetapi sebagai tindakan respons atas anugerah yang Allah sudah berikan terlebih dahulu. Berdasarkan hal ini pengertian tanggung jawab menjadi suatu tindakan menanggung sesuatu dari Allah demi rencana-Nya dengan cara dimana manusia tumbuh dan berkembang dalam keutamaanya (Dewantara, 2017).

Setiap manusia perlu memikirkan seluruh tindakannya bukan untuk menghindar dari kemalangan atau kekeliruan, tetapi melihat dari sudut pandang Allah yang menekankan tindakan Allah yang menyelamatkan manusia dari perkabungan kepada sukacita (Stassen \& Gushee, 2003). Tanggung jawab adalah kesatuan dari etika tugas, kewajiban dan kebajikan. Ketiganya mendorong aktualisasi dari gagasan tanggung jawab 
dengan jelas dan nyata. Boenhoffer sebagaimana dikutip Gushee dan Stassen menjelaskan sebuah partisipasi aktif orang-orang percaya. Orang Kristen bertanggung jawab kepada Allah sebagai yang tertinggi. Dalam semua tindakan dan hubungan kita harus menghormati dan meningkatkan integritas hidup di hadapan Tuhan (dalam Stassen \& Gushee, 2003). Ketika orang percaya menjalankan setiap tindakan yang selaras dengan ajaran Allah itulah makna sesungguhnya dari menghargai anugerah Allah. Akhirnya, Tuhan juga memiliki tanggung jawab-Nya. Prinsip utamanya bahwa Kristus adalah jaminan orang Kristen bahwa Tuhan alam semesta benar dan terlebih dulu bertanggung jawab.

\section{Tanggung Jawab Menjalankan Protokol Kesehatan di Era New Normal}

Keengganan sebagian besar orang untuk mengikuti protokol kesehatan di era New Normal adalah karena kurangnya rasa tanggung jawab untuk turut memutus mata rantai penyebaran Covid-19. Meskipun semua orang menghendaki pandemi segera berakhir, namun hal tersebut kurang diikuti oleh tindakan konkrit untuk berpartisipasi.

Bagi umat Kristen, sesungguhnya menjalankan protokol kesehatan bukanlah sesuatu yang berat untuk dilaksanakan. Hal tersebut, secara etis, melekat kuat pada panggilan hidup sebagai orang percaya. Dalam etika Kristen, orang percaya diajarkan tentang bagaimana hidup yang bertanggung jawab di hadapan Allah dan manusia. Dalam new normal standar yang diberlakukan seperti terkandung dalam 5M (Memakai 
masker, Mencuci tangan pakai sabun dan air mengalir, Menjaga jarak, Menjauhi kerumunan, dan Membatasi mobilisasi dan interaksi). Sebagai orang percaya sepantasnya tidak membiarkan kepatuhan kita muncul karena desakan dan suasana sekitar, tetapi muncul dari kesadaran karena mengasihi Allah dan sesama.

Integritas hidup orang Kristen ditunjukkan dalam kehidupan seharihari. Segala keberadaan dan kemauan kita, apa yang kita lakukan dan apa yang tidak kita lakukan, adalah jawaban yang berkelanjutan atas Firman Tuhan yang disampaikan kepada kita sebagai perintah. Tanggung jawab orang Kristen adalah tentang ketaatan pada perintah Tuhan. Dalam konteks saat ini bertanggungjawab bukan sekedar teori tetapi dipraktikkan sebagai gaya hidup.

Dalam hal ini ia berjalan selaras sebagai bukti manusia mengasihi Allah yang dinyatakan dengan perbuatan, Yakobus mengingatkan untuk berbuat sesuatu sebagai iman kita (Yak. 2:14-26). Iman menjadi dasar penting perbuatan baik manusia, karena tanpa anugerah tersebut segala sesuatu yang diperbuat manusia di hadapan Allah ada salah (Rm.8:8; 14:23). Tanggung jawab Kristen lahir dari perbuatan baik yang didasari oleh iman, bukan kebajikan (virtue) manusia semata. Ini fondasi utama yang bisa membawa orang percaya berkontribusi di tengah pandemi.

Terhadap pandemi Covid-19, seperti dikatakan Stassen \& Gushee, orang Kristen bukan hanya berpikir untuk menghindar dari kemalangan, tetapi harus bisa melihat dari sudut pandang Allah yang yang 
menyelamatkan manusia dari perkabungan kepada sukacita (Stassen \& Gushee, 2003). Kematian tubuh tidak perlu ditakutkan namun bukan berarti memelihara hidup, kesehatan, pola hidup bisa diabaikan.

Orang Kristen wajib berpartisipasi aktif dalam penanggulangan pandemi Covid-19. Partisipasi tersebut merupakan wujud bertanggung jawab kepada Allah sebagai yang tertinggi bahwa dalam semua tindakan dan hubungan kita harus menghormati dan meningkatkan integritas hidup di hadapan Tuhan. Ketika orang percaya menjalankan setiap tindakan yang selaras dengan ajaran Allah itulah makna sesungguhnya berarti menghargai anugerah Allah. Berpartisipasi menjalankan protokol kesehatan merupakan pernyataan integritas hidup di hadapan Allah dan menghargai anugerah Allah dalam kehidupan.

\section{KESIMPULAN}

Tanggung jawab dalam perspektif etika dan teologi Kristen bukan sekedar perwujudan dari moral dan etika manusia yang bernilai, melainkan sebagai cara Allah menggenapkan rencana-Nya bagi orang percaya juga. Tindakan yang bertanggung jawab adalah sikap yang diarahkan untuk memahami panggilan untuk berbuat dalam kesulitan sesama sebagai panggilan Allah sendiri. Cara hidup bertanggung jawab bisa dinyatakan dengan ekspresi di tempat rumit. Ini adalah konteks panggilan gereja untuk bersaksi di tengah pandemi Covid-19, khususnya melalui tanggung jawab menjalankan protokol kesehatan. 


\section{DAFTAR PUSTAKA}

Amani, M. (2020). 20 Negara dengan Kasus Aktif Corona Tertinggi, Indonesia Nomor 14. kompas.com.

Bertens, K. (2013). Etika (15 ed.). Kanisius.

Binti Mufarida. (2021). Kerumunan di Pasar Tanah Abang, IDI: Mudahmudahan Sehat Semua. Sindonews.

Cole, G. A. (1995). Responsible. In D. J. Atkinson \& D. F. Field (Ed.), New Dictionary of Christian Ethics \& Pastoral Theology. InterVarsitiy Press.

Dewantara, A. W. (2017). Filsafat Moral: Pergumulan Etis Keseharian Hidup Manusia. Kanisius.

Douma, J. (2010). Kelakuan yang Bertanggung Jawab (6 ed.). BPK Gunung Mulia.

Huber, W. (2020). Ethics of responsibility in a theological perspective. STJ I Stellenbosch Theological Journal, 6(1), 185-206. https://doi.org/10.17570/stj.2020.v6n1.a11

Kaseke, F. Y. M. (2020). Sabat dan Pandemic Covid-19: Perspektif Ecoteologi Kristen. 9(1), 23-31. https://doi.org/10.47154/scripta.v9i1.110

Kusuma, B. (2020). Cegah Penyebaran Covid-19, Polisi Hentikan Upacara Rambu Solo di Toraja Artikel ini telah tayang di TribunTravel.com dengan judul Cegah Penyebaran Covid-19, Polisi Hentikan Upacara Rambu Solo di Toraja, https://travel.tribunnews.com/2020/12/26/cegah-penye. Tribunnews.com.

Lotulung, G. (2021). Persentase Angka Kematian Covid-19 Indonesia Naik, Ini Analisis Ahli. kompas.com.

Lovin, R. W. (2009). Becoming Responsible in Christian Ethics. Studies in Christian Ethics, 22(4), 389-398. https://doi.org/10.1177/0953946809340939

Luhukay, A. S. (2020). Analisis Teologis Mengenai Beribadah Di Rumah Di Tengah Pandemi Covid-19 Di Indonesia. Visio Dei: Jurnal Teologi Kristen, 2(1), 43-61. https://doi.org/10.35909/visiodei.v2i1.87

Mansur, A. (2020). Kasus Kerumunan Petamburan Disidik, FPI: Diskriminasi Hukum. Republika.

Niebuhr, H. R. (1963). The Responsible Self: An Essay in Christian Moral Philosophy. Harper \& Row.

Schweiker, W. (1999). Responsibility and Christian Ethics. Cambridge University Press.

Schweiker, W. (2009). Responsibility and Moral Realities. Studies in 
Christian Ethics, 22(4), 472-495. https://doi.org/10.1177/0953946809340953

Severson, E. R. (2011). Scandalous Obligation: Rethinking Christian Responsibility. Beacon Hill Press.

Stassen, G. H., \& Gushee, D. P. (2003). Etika Kerajaan: Mengikuti Yesus dalam Konteks Masa Kini. Momentum.

Sukur. (2021). Viral Kerumunan di Objek Wisata Riau, Kebijakan Setengah Hati? Liputan6.

Susanta, Y. K., Yordaniaputra, Y., \& Christian, I. (2020). Ethics Of Responsibilities According To Emmanuel Levinas And Its Implications In The Interfaith Dialogue : Christian Perspectives. Dialog, 43(2), 167176. https://doi.org/10.47655/dialog.v43i2.389 |

Tuwu, D. (2020). Kebijakan Pemerintah Dalam Penanganan Pandemi Covid-19. Journal Publicuho, 3(2), 267-278. https://doi.org/10.35817/jpu.v3i2.12535

Verkyul, J. (2018). Etika Kristen (13 ed.). BPK Gunung Mulia.

Villiers, D. De. (2006). Prospects of a Christian Ethics of responsibility (Part 1): An assessment of an American version. Verbum et Ecclesia, 27(2), 468-487. https://doi.org/10.4102/ve.v27i2.159

Villiers, E. De. (2013). A Christian Ethics of Responsibility: Does It Provide an Adequate Theoretical Framework for Dealing With Issues of Public Morality? Scriptura, 82, 23-38. https://doi.org/10.7833/82-0-895

Wannenwetsch, B. (2005). "Responsible Living" or "Responsible Self"? Bonhoefferian Reflections on a Vexed Moral Notion. Studies in Christian Ethics, 18(3), 125-140. https://doi.org/10.1177/0953946805058804

Wells, S., Quash, B., \& Eklund, R. (2017). Introducting Christian Ethics (2 ed.). Wiley Blackwell. 